\title{
DISTRIBUTION AND STATUS OF THE STAR TORTOISE (GEOCHELONE ELEGANS) IN GUJARAT STATE, INDIA
}

\author{
Raju Vyas $^{1}$ and B.M. Parasharya ${ }^{2}$ \\ ${ }^{1}$ Sayaji Baug Zoo, Vadodara, Gujarat 390018, India. \\ ${ }^{2}$ TAINP on Agricultural Ornithology, Gujarat Agricultural University, Anand, Gujarat 388110, India.
}

\begin{abstract}
The Indian Star Tortoise is widely distributed north of Narmada River in Gujarat State. The species is not common in the state and is mainly found in agricultural fields, and hence associated threats may rapidly decline the population.
\end{abstract}

\section{Introduction}

The Indian Star Tortoise (Geochelone elegans) is the most common tortoise compared to the other three species (Indotestudo elongata, I. forestenii and Manouria emys) found in India (Moll, 1989). The species is widely distributed in the arid parts of Indian subcontinent -- Pakistan (Thar Desert), India (Rajasthan, Gujarat, Karnataka, Andhra Pradesh, Orrisa, Tamil Nadu, Madhya Pradesh and Kerala) and Sri Lanka (Das, 1995). The main land Star Tortoise has two separate populations, on the bases of morphometric characters (Frazier, 1992).

Based on literature and last survey report of Frazier (1987) and Rao and Choudhary (1996) the species has wide distribution throughout the Saurashtra and Kachchh peninsula, North Gujarat, Ahmedabad and Vadodara Districts. Inspite of Frazier's efforts, the number of authentic locality records are small. We made a detailed survey of the species in Gujarat using Frazier's questionnaire (1989).

The species is listed in Schedule IV of the Indian Wildlife (Protection) Act 1972 (amended in 1991) and Appendix II of the CITES.

\section{Methods}

A detail survey was made suring 1989-98, covering the entire state as part of the herpeto and avian fauna diversity study. Information such as present status of Star Tortoise, habitat condition and available potential habitat were recorded. Rapid surveys were conducted in important protected areas of the state to determine the status of this species. In addition, secondary information was gathered from forest personnel, wildlife enthusiasts, animal breeders and local pet trade dealers.

\section{Results}

We collected live tortoises (29 females; 3 males; 1 sub-adult and 2 hatchlings) from 30 localities in 15 districts of the state (Table
1, Map 1). The species was not recorded in the districts south of Narmada River. However, we received secondary information regarding the species occurrence from two localities i.e. Nargol and Umergaov of Valsad District and outskirts of the city of Surat, Surat District (A.A. Shah \& K.S. Bhatt, pers. comm.). The present habitat structure of these areas is such that there is no possibility for the natural existence of Star Tortoise. The secondary information might have been on the basis of accidentally escaped tortoise from private pet collections. We obtained information regarding presence of Star Tortoise from 17 districts out of a total of 19 districts in the state.

Out of the 16 protected areas, the species was found in 11 protected areas (Table 2). There seems to be no special measures taken for the conservation of the species, except the State Forests Department's efforts in Gir National Park and Sanctuary. A few specimens are kept at the crocodile hatchery at Sasan for claimed breeding purposes. Every year, the State Forests Department takes preventive measures against forest fires by drawing fire lines in all deciduous protected areas, which has a negative impact on the species population. The fire lines are made by clearing land by burning vegetation in 10-12 meters long paths and dividing the entire forest into many compartments, which in Gir covers a minimum of 2-4 per cent of forest area.

\section{Pet trade}

The Indian Star Tortoise in one of the most popular pets today. We found the species as pet in 25-100 houses each in all major cities of the state. Specimens that have been in captivity for 1040 years were examined at Ahmedabad, Bhavnagar, Jamnagar, Surat and Vadodara. Also many farmhouses and captive breeders maintained a small population to breed them regularly.

Annually, some (50-75 approx.) tortoises are collected from the wild and sold in local markets of major cities of the state. In addition a few tortoises come from the zoos and captive breeders and get into illegal pet trade.

Star Tortoise trade statistics by confiscation internationally and within India (Table 3) show that more than 5,000 tortoise were illegally caught from the wild during 1991-97. One thousand eight hundred tortoise in two different consignments seized at Amsterdam, Netherlands and Adipur, Kachchh, India indicate that the entire stock was from the west coast of India (Anon, 
Table 1 Locality recorded for live G. elegans during the present study

\begin{tabular}{|c|c|c|}
\hline Districts/Locality & No. sighted (Sex) & Habitat \\
\hline \multicolumn{3}{|l|}{ AHMEDABAD } \\
\hline 1. Koth & 1 (Female) & Scrub land \\
\hline 2. Sarkhej & 1 (Female) & Babul forest \\
\hline \multicolumn{3}{|l|}{ AMRELI } \\
\hline $\begin{array}{l}\text { 3. Dhari } \\
\text { BANASKANTHA }\end{array}$ & 1 (Female) & Scrub land \\
\hline 4. Dhanera & 3 (Females) & Scrub land \\
\hline 5. Dantivada & 1 (Hatchling) & Agriculture field \\
\hline 6. Iqbalgadh & 1 (Female) & Scrub land \\
\hline 7. Palanpur & 1 (Female) & Agriculture field \\
\hline \multicolumn{3}{|l|}{ BHAVNAGAR } \\
\hline 8. Sihar & 1 (Female) & Grass land \\
\hline \multicolumn{3}{|l|}{ GANDHINAGAR } \\
\hline 9. Koba & 1 (Female) & Agriculture field \\
\hline \multicolumn{3}{|l|}{ JAMNAGAR } \\
\hline 10. Lalpur & 1 (Female) & Agriculture field \\
\hline \multicolumn{3}{|l|}{ JUNAGADH } \\
\hline 11. Satadhar & 1 (Sub-adult) & Scrub land \\
\hline \multicolumn{3}{|l|}{ KHEDA } \\
\hline 12. Chakalasi & 1 (Female) & Agriculture field \\
\hline 13. Borsad & 1 (Female) & Agriculture field \\
\hline 14. Isanpur & 1 (Female) & Agriculture field \\
\hline 15. Kapadvanj & 1 (Female) & Agriculture field \\
\hline 16. Mahemdabad & 1 (Female) & Agriculture field \\
\hline 17. Sevalia & 2 (Male, Female) & Scrub land \\
\hline \multicolumn{3}{|l|}{$\mathrm{KACHCHH}$} \\
\hline 18. Dhrul & 1 (Female) & Agriculture field \\
\hline 19. Borana, Nanavadiya & 1 (Female) & Agriculture field \\
\hline 20. Samaghogha & 1 (Female) & Agriculture field \\
\hline \multicolumn{3}{|l|}{ MAHESANA } \\
\hline 21. Becaraji & 1 (Female) & Scrub land \\
\hline 22. Vijapur & 1 (Female) & Agriculture field \\
\hline \multicolumn{3}{|l|}{ PANCHMAHAL } \\
\hline 23. Chapaner & 2 (Females) & Scrub land \\
\hline \multicolumn{3}{|l|}{ RAJKOT } \\
\hline 24. Vankaner & 1 (Female) & Agriculture field \\
\hline \multicolumn{3}{|l|}{ SABARKANTHA } \\
\hline 25. Vatrak & 1 (Hatchling) & Agricultural Field \\
\hline 26. Idar & 1 (Female) & Scrub Land \\
\hline \multicolumn{3}{|l|}{ SURENDRANAGAR } \\
\hline 27. Dhangadhra & 1 (Male) & Babul Forest \\
\hline 28. Wadhvan & 1 (Female) & Scrub Land \\
\hline Total number of tortoises & 35 & \\
\hline
\end{tabular}

1997; Choudhury \& Bhupathy, 1993; Katwal, 1996; Tiwari, 1996). On the basis of examination of the seized specimens, the authorities suspect that the origin of the tortoises was Gujarat State.

Present data indicates a high demand for Star Tortoise in the international pet trade market. It is also very clear that a systematic network is active both at national and international level engaging people in collection of live specimens, shipment of stock and its despatch. Such on going trade is a warning to the authorities to develop new strategies for tackling trade and enforcement of law.

\section{Captive population}

We recorded tortoise in nine captive centres (Table 4). Barring the Surat and Rajkot zoos, all captive centres breed the species regularly, but none of them take keen interest in further care of the hatchling or in their research, except Sayaji Baug Zoo, Vadodara (Acharjyo, 1999). We also noticed that a few royal families still maintain a small breeding population of this species.

Most people in Gujarat are vegetarians and believe in saving animals, but a few tribals, especially Vaghari and Bhil hunt the tortoise for food. Some temples (e.g. Golibar Hanuman, Bhavnagar; Haveli and Nav-garh temples, Vadodara; Bhimnath Mahadev, Ahmedabad) maintain a few Star Tortoises for their devotees. It is believed that offering prayers to Star Tortoise can lead to better and longer life. The Star Tortoise is known in various Gujarati vernacular names depending upon the region.

Threats to the species

We could recognise four major threats to the survival of this species. They are habitat destruction, agricultural practice, pet trade and forest management.

\section{Discussion}

Star Tortoise (Geochelone elegans) is widely distributed throughout the state but not south of Narmada. It seems that the river has served as physical barrier for its distribution in the state.

During the survey, over 50 per cent of the specimens were collected form agricultural fields, which is a secondary habitat. Since agricultural landscape is changing very fast due to industrialisation, the species is likely to disappear soon.

Habitat destruction is the main threat to the species. The protected areas are limited and distributed far apart. Even protected areas are prone to fragmentation or alteration. Certain management practices of the protected area have adverse effects on the species (e.g. fire line, wall construction to demarcate area, elevated roads and vehicular traffic and railway line which prevents free movement of animals and often leads to accidental death).

The present distribution pattern, changing habitat structure, status of the species in protected areas, survival potential of a large population in the agricultural landscape and possible indirect or direct threats to the species suggests an uncertain future of this species in the state of Gujarat. It calls for immediate action of drafting new strategies and management plans for stabilising the wild population of the Indian Star Tortoise.

\section{Acknowledgement}

We thank Dr. Jack Frazier who inspired us to intiate this study and Shri J.J. Jani and Dr. K.L. Mathew who collected specimens and provided valuable information on locality and habitat. We thank several friends who generously provided information on the species. 
Table 2. Present status of the Indian Star tortoise (G. elegans) in the Protected Area of Gujarat.

\begin{tabular}{lllll}
\hline No. & Name of the Protected Area. & $\begin{array}{l}\text { Area of the } \\
\text { PA }(\mathbf{s q} . \mathbf{k m})\end{array}$ & $\begin{array}{l}\text { Presence(P)I } \\
\text { Absence(A) }\end{array}$ & Status* \\
\hline 1 & Balaram-Ambaji Wildlife Sanctuary & 542.08 & $\mathrm{P}$ & Common \\
2 & Jessore Sloth bear Sanctuary & 180.66 & $\mathrm{P}$ & Common \\
3 & Jamughoda Wildlife Sanctuary & 130.38 & $\mathrm{~A}$ & - \\
4 & Ratanmahal Wildlife Sanctuary & 55.65 & $\mathrm{~A}$ & - \\
5 & Shoolpaneshwar Wildlife Sanctuary & 607.0 & $\mathrm{~A}$ & - \\
6 & Vansda National Park & 23.99 & $\mathrm{~A}$ & - \\
7 & Barada Wildlife Sanctuary & 192.31 & $\mathrm{P}$ & Uncommon \\
8 & Gir National Park \& Sanctuary & 1414.13 & $\mathrm{P}$ & Common \\
9 & Hingolgadh Nature Education Sanctuary & 6.54 & $\mathrm{P}$ & Uncommon \\
10 & Pania Wildlife Sanctuary & 39.63 & $\mathrm{P}$ & Uncommon \\
11 & Rampara Wildlife Sanctuary & 15.01 & $\mathrm{P}$ & - \\
12 & Velavadar National Park & 38.08 & $\mathrm{~A}$ & Uncommon \\
13 & Gaga Bustard Sanctuary & 3.33 & $\mathrm{P}$ & Uncommon \\
14 & Wild Ass Sanctuary & 4953.70 & $\mathrm{P}$ & Uncommon \\
15 & Lalaji Bustard Sanctuary & 2.03 & $\mathrm{P}$ & Common \\
16 & Narayan Sarovar Chinkara Sanctuary & 765.79 & & \\
\hline
\end{tabular}

*Based on State Forests Department and personal assessments of the area.

\section{References}

Acharjyo, L.N. (1999). Role of zoos in the conservation of reptiles in India. Cobra (33):15-22.

Anon (1997). Star tortoise trade. Oryx 31(3):170.

Das, I. (1995). Turtles and tortoise of India. W.W.F. India and Oxford University Press, Bombay, 176 pp.

Choudhury B.C. and S. Bhupathy (1993). Turtle trade in India: A study of tortoise and freshwater turtles. W.W.F. India, New Delhi, 50 pp.

Frazier, J. (1987). Biology and conservation of Indian turtles and tortoises. Interim report to the American Institute for Indian Studies, New Delhi, 64 pp.

Frazier, J. (1989). Have you seen the star of India? Hornbill (2):3-6.
Frazier, J. (1992). Management of tropical chelonians: Dream or nightmare?. In: Tropical Ecosystem: Ecology and Management. K.P. Singh and J.S. Singh (Eds.), pp. 125-135. Wiley Eastern Limited, New Delhi.

Katwal, R.P.S. (1998). A new rescue centre in an established zoo: The Arignar Anna Zoological Park, India. Zoos' Print 13(8): 26-28.

Rao, R.J. and B.C. Choudhury (1996). Prospect of captive breeding and restocking of star tortoise in Gujarat. Zoos' Prin. 11(10): 1-4.

Tiwari, J.K. (1996). Star Tortoise. Kachchh Mitra, News Paper 2nd March (Gujarati).

Moll, E.O. (1989). Geochelone elegans, Indian Star Tortoise. In: The Conservation biology of tortoise. Swingland I.R. and M.W. Klemens (Eds), pp. 113-114, Occ. Pap. IUCN/SSC No. 5.

Table 3. The star tortoise (G. elegans) confiscation by law enforcement authorities in India and abroad, during 1991-1997.

\begin{tabular}{llll}
\hline $\begin{array}{l}\text { No. of } \\
\text { tortoise }\end{array}$ & Place and authority & Year & Source of information \\
\hline 0292 & $\begin{array}{l}\text { Pet shop \& Air Port, Calcutta, } \\
\text { India. West Bengal Forests Department }\end{array}$ & $1991-1993$ & Kalayan Das, 1993 (pers. comm.) \\
0200 & $\begin{array}{l}\text { Amsterdam Air Port, } \\
\text { Netherlands }\end{array}$ & 1993 & Choudhury and Bhupathy, 1993 \\
1600 & $\begin{array}{l}\text { Adipur Port, Kachchh, } \\
\text { India }\end{array}$ & 1993 & Tiwari, 1996 \\
1000 & $\begin{array}{l}\text { Official forest report, } \\
\text { India } \\
\text { Canadian customs }\end{array}$ & 1996 & Anon, 1997 \\
232 & Chennai Air Port, India & $1990-1997$ & On three occasions. Katwal, 1998 \\
2000 & & & \\
Total: 5124 & &
\end{tabular}




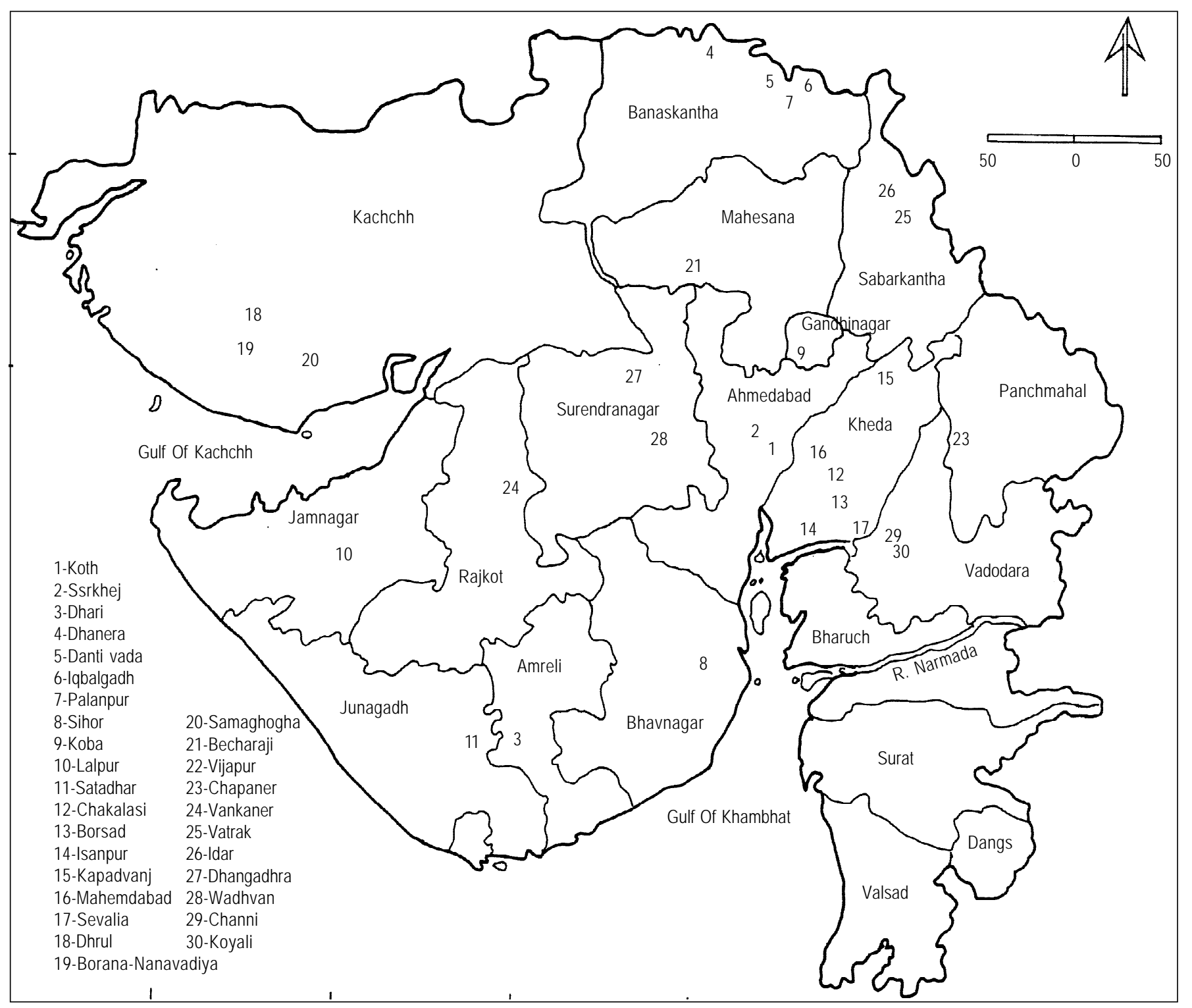

Figure 1. Map of Gujarat showing locality records for Star Tortoise.

Table 4. List of zoos and captive centres maintaining and breeding G. elegans in Gujarat (up to July 1999).

\begin{tabular}{lllllll}
\hline No. & Name & Breeding & Male & Female & Unsexed & Total \\
\hline 1 & Kankaria Zoo, Ahmedabad & B & 12 & 23 & 13 & 48 \\
2 & Sundervan, Ahmedabad & B & & & 36 & 36 \\
3 & Indroda Park, Gandhinagar & B & 3 & 9 & & 12 \\
4 & Sakkarbaug Zoo, Junagadh & B & 4 & 9 & 13 \\
5 & RajkotZoo, Rajkot & - & 4 & 8 & & 12 \\
6 & Sayaji Baug Zoo, Vadodara & B & 12 & 13 & 25 & 50 \\
7 & Sasan Crocodile Rearing Centre, & & & & & 79 \\
8 & Sasan, Junagadh & B & 5 & 11 & & 21 \\
9 & Peter Scott Trust, Jamnagar & B & 5 & 16 & & 12 \\
& SuratZoo, Surat & - & 1 & 11 & & 283 \\
\hline
\end{tabular}

